\title{
An Endogenous Growth Model of a Financially Repressed Small Open Economy
}

\author{
Samrat Goswami ${ }^{\text {a }}$ and Rangan Gupta ${ }^{\text {b }}$ \\ ${ }^{a}$ ICFAI Business School Research Center, Kolkata, India \\ ${ }^{\mathrm{b}}$ Department of Economics, University of Pretoria, South Africa
}

\begin{abstract}
The paper develops a monetary endogenous growth model of a financially repressed small open economy, characterized by curb markets, capital mobility, transaction costs in domestic and foreign capital markets, and a flexible exchange rate system, to analyze the impact of financial liberalization - interest rate deregulation and lower multiple reserve requirements - on growth and inflation. When the model is calibrated to match world figures, we find that interest rate deregulation enhances growth and reduces inflation in steady-state. For relatively smaller transaction costs in the curb market, the above result is, however, reversed. Under such circumstances, lowering the transaction costs in the foreign capital market tends to restore the growth-enhancing (inflation-reducing) capabilities of interest rate deregulation. Lower reserve requirements, though, always ensures lower (higher) steady-state inflation (growth).

Keywords: Financial repression; growth and inflation; unofficial financial markets; monetary policy

JEL Classification: E22; E26; E31; E44; E52
\end{abstract}

\section{Introduction}

This paper develops a monetary endogenous growth model of a financially repressed small open economy in an overlapping generations framework, characterized by Unofficial Money Markets (UMM) or curb markets, as popularly called, capital mobility, costs involved in carrying out transactions in domestic and foreign capital markets, and a flexible exchange rate system, to analyze the impact of financial liberalization on growth and inflation. To note, the term 'financial repression' was originally coined by economists interested in less developed countries (LDCs). In their seminal, but independent, contributions, McKinnon (1973) and Shaw (1973) were the first to spell out the notion of financial repression, defining it as the set of government legal restrictions preventing the financial intermediaries in the economy from functioning at full capacity.

Generally, financial repression consists of three elements. First, the banking system is forced to hold government bonds and money through the imposition of high reserve and liquidity ratio requirements. This allows the government to finance budget deficits at a low or zero cost. Second, given that government revenue cannot be extracted that easily from private securities, the development of private bond and equity markets is discouraged. Finally, the banking system is characterized by interest rate ceilings to prevent competition with public sector fund raising from the private sector and to encourage low-cost investment. Thus, the regulations generally 
includes interest rate ceilings, compulsory credit allocation, and high reserve requirements.

Since the break-up of the colonial empires, many developing countries suffered from stagnant economic growth, high and persistent inflation, and external imbalances under a financially repressed regime. To cope with these difficulties economic experts, popularly referred to as the 'Liberal School' in the literature, had advocated what they called 'financial liberalization' - mainly a high interest rate policy to accelerate capital accumulation, hence growth with lower rates of inflation (McKinnon, 1973; Shaw, 1973; Kapur, 1976; Matheison, 1980). Their argument that relaxation of the institutionally determined interest rate ceilings on bank deposit rates would lead to price stabilization and long-run growth through capital accumulation is based on the following chronology of events: (a) the higher deposit rates would cause the households to substitute away from unproductive assets (foreign currency, cash, land, commodity stocks, and so on) in favor of bank deposits; (b) this in turn would raise the availability of deposits into the banking system, and would enhance the the supply of bank credit to finance firms' capital requirements; and (c) this upsurge in investment would cause a strong supply side effect leading to higher output and lower inflation. ${ }^{1}$

Against such a backdrop, the motivation for our study arises from the dearth in the literature of microfounded monetary endogenous growth models for small open economies subjected to financial restrictions. ${ }^{2}$ There are, however, two noteworthy exceptions: Kang \& Sawada (2000) and Gupta (2007). Kang \& Sawada (2000) presented an endogenous growth model that simultaneously incorporated the role of financial development, human capital investment and external openness. The study indicated that financial development and trade liberalization increases the growth rate of the economy by enhancing the marginal benefits of human capital investment and vice versa. The paper, thus, advocates openness and financial development as the basic requirements of sustainable economic development.

While, Gupta (2007) analyzes the effects of financial liberalization on inflation. The paper develops an open economy monetary endogenous growth general equilibrium model, with financial intermediaries subjected to an obligatory 'high' reserve ratio, serving as the source of financial repression. When calibrated to four Southern European semi-industrialized countries, namely Greece, Italy, Spain and Portugal, which typically had high reserve requirements, the model indicated a positive inflation-financial repression relationship.

However, these two studies have a major limitation, in the sense that, neither of the abovementioned two analyses incorporate the role of Informal or Unorganized Money Markets (UMM), and such an exclusion leads to incomplete, if not incorrect analysis of financial liberalization. The importance of curb market loans in financing investment requirements, and, hence, its impact on the process of financial liberalization, has been theoretically stressed a lot in the literature by the so-called 'New-Structuralist School' (see, for example Van Wijnbergen, 1982, 1983 and 1985; Taylor, 1983; Buffie, 1984; Kohsaka, 1984; Lim, 1987). These authors indicate that the UMM, or popularly the 'curb' markets, are an integral component of the financial structure of the developing countries, and they provide more rather than less intermediation when compared with the banking system, simply because the 'curb' markets are not subjected to interest rate and reserve requirement policies. Van Wijnbergen (1982, 1983 and 1985) outlines the UMM as a 'residual' market absorbing the excess demand for credit from the 
banking system and, in turn, clearing the entire market for credit. They argue that in a world with multiple savings options in the form of unproductive assets, interest bearing bank deposits, and UMM securities, interest rate deregulation can cause a reallocation in households portfolio in favor of bank deposits at the cost of the unproductive assets and the UMM securities. If this reallocation is mainly at the expense of 'curb' market securities, then the total supply of credit would fall, since, unlike the banking system, which is subjected to reserve requirements, the UMM provides one to one intermediation. The credit-squeeze in the financial market would now push up the UMM rate and create a cost-push effect on aggregate supply, lowering capital accumulation, output and raising inflation. Hence, financial liberalization, in the presence of UMM can be stagflationary.

The New-Structuralist claims were, traditionally, based on short-run, reduced-form-equations, that lacked any microfoundations. These claims have, however, been formalized recently by Bencivenga \& Smith (1991) and Espinosa \& Yip (1996) using proper microfounded endogenous growth models. They show that, unless, financial repression is severe enough to generate curb markets, financial liberalization enhances growth and lowers inflation. However, in the presence of curb markets, financial liberalization is inflationary and puts the economy onto a lower growth path. But these analyses, just as the entire New-Structuralist thought process, are based on closed economy assumptions. Moreover, their treatment of the curb markets is somewhat ad hoc and lacks motivation as to why agents in the model decide to intermediate a fraction of the capital through the informal capital market. We, however, avert such an issue by deriving a curb market loan supply function, depending on interest rate differentials in the official and unofficial markets and individual income, based on the utility-maximization behavior of agents. More importantly, the work of Bencivenga \& Smith (1991) and Espinosa \& Yip (1996) uses a spatial economy model. This style of modeling monetary economies, although theoretically very insightful, renders the framework incapable of calibration, and, hence, cannot be applied to country-specific analysis.

Under such circumstances, the current paper develops a more realistic model of a financially repressed economy, based on proper microfoundations, characterized by unofficial money markets, flexible exchange rates and capital mobility, to analyze the effects of financial liberalization on growth and inflation. This study, thus, simultaneously, extends the papers of Kang \& Sawada (2000) and Gupta (2007), on one hand, and the studies of Bencivenga \& Smith (1991) and Espinosa \& Yip (1996) on the other. Moreover, given the modeling structure, the study can be easily applied to a specific country. The existing analysis, however, does not calibrate the model to any specific country, but relies mostly to match the (average) world figures. And finally, even though Kang \& Sawada (2000) and Gupta (2007) allow for perfect capital mobility, they ignore the importance of transaction costs involved in trading in the foreign bonds market, as stressed by Bacchetta \& Caminal (1992). As we will see below, these costs have important implications on the final outcome of a policy of financial deregulation on growth and inflation. The paper is organized as follows: Besides the introduction and the conclusions, sections 2 and 3, respectively, lay out the economic environment and define the equilibrium. Section 4 analyzes the effect of financial liberalization on growth and inflation. 


\section{The Economic Environment}

In this section, the overlapping generations model of Diamond (1965) is modified to depict a financially repressed structure of a small open economy. The economy is populated by four types of agents, namely, consumers, banks (financial intermediaries), firms and an infinitely-lived government. The following subsections lay out the economic environment in detail, by considering each of the agents separately and accounting for the external sector.

\subsection{Consumers}

The economy is characterized by an infinite sequence of two-period-lived overlapping generations of consumers. Time is discrete and is indexed by $t=1,2, \ldots$ At each date $t$, there are two coexisting generations-young and old. $N$ people are born at each time point $t \geq 1$. At $t=1$, there exist $N$ people in the economy, called the initial old, who live for only one period. Hereafter $N$ is normalized to 1 .

Each agent is endowed with one unit of working time $\left(n_{t}\right)$ when young and is retired when old. The agent supplies this one unit of labor inelastically and receives a competitively determined real wage of $w_{t}$. We assume that the agents consume only when old ${ }^{3}$ and, hence, the net of tax wage earnings is allocated between bank deposits, loans in the curb market and foreign bonds. ${ }^{4}$ The proceeds from the bank deposits, the curb market loans and foreign bonds are used to obtain second period consumption. The consumption bundle comprises a domestically produced good and an imported foreign good. We assume a separable and additive log-utility function in the two goods. To allow for simultaneous holding of curb market loans (foreign bonds) and deposits in the consumer portfolio, given that the interest rate in the UMM (world market) is much higher compared with the controlled deposit rate, we assume the curb market loans (foreign bonds) to be subjected to transactions and information costs, as in Owen \& Solis-Fallas (1989), Bacchetta \& Caminal (1992) and Haslag \& Young (1998). These costs are assumed to be an increasing and convex function in UMM loans (foreign bonds).

Formally, the agents problem born in period $t$ is as follows:

$$
\begin{aligned}
& U\left(c_{t+1}, c_{t+1}^{*}\right)=\sigma \log c_{t+1}+(1-\sigma) \log c_{t+1}^{*} \\
& p_{t} d_{t}+p_{t} l_{t}^{c}+\left(e_{t} p_{t}^{*}\right) b_{t}^{*} \leq\left(1-\tau_{t}\right) p_{t} w_{t} \\
& p_{t+1} c_{t+1}+\left(e_{t+1} p_{t+1}^{*}\right) c_{t+1}^{*} \leq\left\{\begin{array}{c}
\left(1+\bar{i}_{d t+1}\right) p_{t} d_{t}+\left(1+i_{t+1}^{c}\right) p_{t} l_{t}^{c}-p_{t} \frac{1}{2} c_{1}\left(\frac{l_{t}^{2}}{w_{t}}\right) \\
+\left(1+i_{t+1}^{*}\right)\left(e_{t} p_{t}^{*}\right) b_{t}^{*}-\left(e_{r} p_{t}^{*}\right) \frac{1}{2} c_{2}\left(\frac{b_{t}^{t 2}}{w_{t}}\right)
\end{array}\right\}
\end{aligned}
$$

where $U(\cdot)$ is the utility function, 5 with the standard assumption of positive and diminishing marginal utilities in both goods; $\sigma(1-\sigma)$ is the weight the consumer assigns to the domestic (foreign) good in the utility function; $c_{t+1}$ and $c_{t+1}^{*}$ are the old age consumption of domestic and foreign good, respectively; $d_{t}, l_{t}^{c}$ and $b_{t}^{*}$ are the real deposits, curb market loans and foreign 
bonds held in period $t$, respectively; $\tau_{t}$ is the tax rate at period $t ; p_{t}\left(p_{t}^{*}\right)$, is the price of the domestic (foreign) consumption good at period $t ; e_{t+1}$ is the nominal exchange rate; $\bar{l}_{d t+1}, i_{t+1}^{c}$ and $i_{t+1}^{*}$ the controlled nominal interest rate on bank deposits and the nominal interest rate prevailing in the UMM and the world market, respectively, with $i_{t+1}^{c}>\bar{i}_{d t+1}$ and $i_{t+1}^{*}>\bar{i}_{d t+1}$; and $\frac{1}{2} c_{1}\left(l_{t}^{c 2} / w_{t}\right)$ and $\frac{1}{2} c_{2}\left(b_{t}^{* 2} / w_{t}\right)$ capture the capture the real information and transaction costs involved when making loans in the curb market and buying foreign bonds, respectively, with $c_{i}>0$ for $i=1,2$, being the cost parameters. Alternatively, these costs can be viewed as resource losses in averting government regulations imposed on transactions in the curb and foreign bond markets. However, as Gupta \& Karapatakis (2008) points out, government is likely to have a higher capability in controlling the foreign bonds market than the unofficial money market, and hence, these costs in the curb markets are likely to be more structural in nature. As Cho (1990) points out, that these costs may arise due to the issue of a matching problem between individual borrowers and lenders, unlike in the case of a bank, which can pool resources to be lent out. These forms are in line with the transaction cost formulations of Feenstra (1986), Wang \& Yip (1992) and Walsh (2000), and is, simultaneously, consistent with endogenous growth, ${ }^{6}$ ensured by the production structures discussed below. The above form satisfies the assumptions of increasing and convexity of the cost in the amount of curb market loans. ${ }^{7}$ Moreover, such a formulation helps in obtaining Tobin-type demand or supply functions for the assets. Note that the real resources spent in the process of transaction in the curb and foreign bond markets are decreasing in the real wage. Intuitively, this tend to suggest that as the agent becomes richer, for each and every unit of curb market loans made or of foreign bonds purchased, the amount of resources he needs to part with, falls, possibly due to better contacts developed with agents in these markets or government officials, as the economy evolves over time. ${ }^{8}$

Note that utility maximization is equivalent to maximizing the old-age consumption utility function with respect to $c_{t+1}^{*}$ and $l_{t}^{c}$ and $b_{t}^{*}$. The maximization problem of the consumer yields the following optimal choices:

$$
\begin{aligned}
l_{t}^{c} & =\left(\frac{i_{t+1}^{c}-\bar{i}_{d t+1}}{c_{1}}\right) w_{t} \\
b_{t}^{*} & =\left(\frac{i_{t+1}^{*}-\bar{i}_{d t+1}}{c_{2}}\right) w_{t} \\
d_{t} & =\left(\left[1-\tau_{t}\right]+\left(\frac{c_{1}+c_{2}}{c_{1} c_{2}}\right) \bar{i}_{d t+1}-\left[\frac{i_{t+1}^{c}}{c_{1}}+\frac{i_{t+1}^{*}}{c_{2}}\right]\right) w_{t} \\
c_{t+1} & =\sigma\left(\frac{1}{\pi_{t+1}}\right)\left[\left(1+\bar{i}_{d t+1}\right)\left(1-\tau_{t}\right)+\frac{c_{2}\left(i_{t+1}^{c}-\bar{i}_{d t+1}\right)+c_{1}\left(i_{t+1}^{*}-\bar{i}_{d t+1}\right)}{2 c_{1} c_{2}}\right] w_{t} \\
c_{t+1}^{*} & =(1-\sigma)\left(\frac{1}{\pi_{t+1}}\right)\left[\left(1+\bar{i}_{d t+1}\right)\left(1-\tau_{t}\right)+\frac{c_{2}\left(i_{t+1}^{c}-\bar{i}_{d t+1}\right)+c_{1}\left(i_{t+1}^{*}-\bar{i}_{d t+1}\right)}{2 c_{1} c_{2}}\right] w_{t}
\end{aligned}
$$

Note that the supply function of deposits and curb-market loans and the demand functions for 
foreign bonds conform to traditional supply-demand theory of assets. We are assuming that the Purchasing Power Parity (PPP) condition, $p=e p^{*}$ holds. Since $p^{*}$ is parametrically given to the small-open economy, we set it to unity without any loss of generality. Hence, implying that the domestic price level and the nominal exchange rates are synonymous for the model economy with the PPP condition satisfied, i.e. $p_{t}=e t$. Note $p_{t+1} / p_{t}=\pi_{t+1}$ is the gross rate of inflation. Finally, the no-arbitrage condition between curb market loans and foreign bonds requires $i_{t+1}^{c}+\frac{1}{2}\left(i_{t+1}^{c}-\bar{i}_{d t+1}\right)=i_{t+1}^{*}+\frac{1}{2}\left(i_{t+1}^{*}-\bar{i}_{d t+1}\right)$, or, simply ${ }_{t+1}^{c}=i_{t+1}^{*}$ to hold for all $t$.

\subsection{Financial Intermediaries}

The financial intermediaries, in this economy, behave competitively but are subjected to controlled interest rates and multiple reserve requirements. The banks provide a simple pooling function, along the lines described in Bhattacharya \& Haslag (2001) and Chari et al. (1995), by accumulating deposits of small savers and loaning it out to firms after meeting the cash reserve and government bond reserve requirements. For simplicity, bank deposits are assumed to be oneperiod contracts, guaranteeing a controlled nominal return of $\overline{i_{d t}}$ with a corresponding controlled nominal loan rate of $\bar{l}_{t}$. Generally, in a repressed regime, both the deposit and loan rates are set well below the market clearing level. ${ }^{9}$

Note the rate of return on the government bonds is generally very low and hence the reserve requirement on them serves to generate a forced demand. For the sake of simplicity we will assume them to yield a zero rate of return. ${ }^{10}$ Given such a structure, the real profit of the intermediary can be defined as follows:

with:

$$
\begin{aligned}
\Pi_{B t}=\bar{i}_{l t} l_{t}-\bar{i}_{d t} d_{t} \\
m_{t}+b_{t}+l_{t} \leq d_{t} \\
m_{t} \geq \gamma_{1 t} d_{t} \\
b_{t} \geq \gamma_{2 t} d_{t}
\end{aligned}
$$

where $\Pi_{B t}$ is the profit of the bank in real terms at period $t ; l_{t}$ is the loans in real terms at period $t$. Equation (10) ensures the feasibility condition, and $b_{t}$ and $m_{t}$, respectively, are banks holdings of government bonds and fiat money in real terms. The banks are also subject to the multiple reserve requirements on cash and government bonds, given by equations (11) and (12).

The solution to the bank's profit maximization problem results from free entry, driving profits to zero and is given by:

$\bar{i}_{l t}\left(1-\gamma_{1 t}-\gamma_{2 t}\right)-\bar{i}_{d t}=0$

Simplifying, in equilibrium, the following condition must hold: 


$$
\bar{i}_{l t}=\frac{\bar{i}_{d t}}{1-\gamma_{1 t}-\gamma_{2 t}}
$$

As is observed, from equation (14) the solution to the bank's problem yields a loan rate higher than the interest rate on the deposits, since reserve requirements tend to induce a wedge between borrowing and lending rates. Given the multiple reserve requirements and the controlled interest rate on deposits, the nominal interest rate on the loans is also controlled and determined from equation (14).

\subsection{Firms}

All firms are identical and produces a single final good using a Cobb-Douglas type production function, given as follows:

$y_{t}=A k_{t}^{\alpha}\left(n_{t} \overline{k_{t}}\right)^{1-\alpha}$

where $y_{t}$ is the output; $n_{t}$ is the hours of labor supplied inelastically to production in period $t ; k_{t}$ is the per-firm capital stock in period $t$; $\bar{k}_{t}$ denotes the aggregate capital stock in period $t$; $A$ is a positive scalar; and $0<\alpha<1$, is the elasticity of output with respect to capital. Following Romer (1986), the aggregate capital stock enters the production function in equation (15) to account for a positive externality indicating an increase in labor productivity as the society accumulates capital stock. It must be noted that, in equilibrium, $k_{t}=\bar{k}_{t}$.

At time $t$, the final good can either be consumed (domestically or exported) or stored. Firms operate in a competitive environment and maximize profit, taking the wage rate, the rental rate on capital and the price of the consumption good as given, as well as, $\overline{k_{t}}$. Given that both interest rates on deposits and loans are controlled and subject to a ceiling, there exists an excess demand for loans in the official loan market. However, the UMM serves as the 'residual' market and absorbs the excess demand for loans from the banking system and in turn clears the entire market for credit. Hence, the interest cost in the unofficial market defines the true marginal cost (rental rate) of production for the firms, with the loan rate in the official market having no disciplinary effect on the behavior of the firms given the existence of credit rationing. Thus, the producers convert available bank loans, $l_{t}$, and curb market loans, ${ }_{t}^{c}$, into fixed capital formation such that $p_{t} i_{k t}=p_{t}\left[l_{t}+l_{t}^{c}\right]$, where $i_{t}$ denotes the investment in physical capital. Notice that the production transformation schedule is linear so that the same technology applies to both capital formation and the production of consumption goods for domestic agents and export, and, hence, both investment and consumption (domestic and export) goods sell for the same price $p_{t}$.

Empirical evidence of the importance of curb market loans in financing investment expenditures can be found in Van Wijnbergen (1985), Lim (1987), Christensen (1993), Gupta \& Lensink (1996), Kan (2000), Dasgupta (2004, 2005a, b). Van Wijnbergen (1985) and Lim (1987) even validate the stagflationary claim of financial liberalization for South Korea and the Phillipines, respectively, by taking into account the informal money market. Christensen (1993) argued that the informal financial sector is more adept than the formal sector in reducing default risks by the use of a collateral substitute and, hence, is a major source of financing investment in developing 
countries. He, however, warned that informal market loans might be restrictive as well, in the sense, that they might be used to finance small-scale investments. Montiel et al. (1993) indicates that the share of informal finance in total finance seems to range between one-third to about three-quarters. More recently, Gupta \& Lensink (1996) points out that informal financing is not only important in providing rural credit but is also dominant in urban areas of developing countries, such as India, Bangladesh and the Philippines. Kan (2000) investigated the informal financial channels of capital accumulation by household investors. The empirical evidence drawn from micro-data of Taiwan between 1977-92 indicated that the informal channels were heavily relied on by business entrepreneurs. More recently, Dasgupta (2004, 2005a, 2005b) indicated the importance of informal money lenders in financing investment for the case of India. The predominance of informal finance led the author to include the money lenders as an explicit sector in the dynamic general equilibrium model calibrated for India based on household survey data.

We follow Diamond \& Yellin (1990) and Chen et al. (2000) in assuming that the goods producer is a residual claimer, i.e. the producer ingests the unsold consumption good (which is not exported), in a way consistent with lifetime maximization of value of the firms. This ownership assumption avoids unnecessary Arrow-Debreu redistribution from firms to households and simultaneously maintains the general equilibrium nature.

The representative firm at any point of time $t$ maximizes the discounted stream of profit flows subject to the capital evolution and loan constraints. Formally, the problem of the firm can be outlined as follows:

$$
\begin{gathered}
\max _{k_{t+1}, n_{t}} \sum_{i=0}^{\infty} \rho^{i}\left[p_{t} y_{t}-p_{t} w_{t} n_{t}-p_{t}\left(1+i_{t}^{c}\right) l_{t}^{c}-p_{t}\left(1+\bar{i}_{l t}\right) l_{t}\right] \\
K_{t+1} \leq\left(1-\delta_{k}\right) k_{t}+i_{k t} \\
p_{t} i_{k t} \leq p_{t}\left[l_{t}^{c}+l_{t}\right] \\
l_{t} \leq\left(1-\gamma_{1 t}-\gamma_{2 t}\right) d_{t}
\end{gathered}
$$

where $\rho$ is the firm owner's discount factor, and $\delta_{k}$ is the constant rate of capital depreciation. The firm solves the above problem to determine the demand for labor and investment in period $t$, or the gross amount of capital to be carried over to period $t+1$. Given the regulated interest rates in the official loan market and, hence, credit rationing, the firms obtain a fixed amount of loans supplied inelastically by the banks. The term $p_{t}\left(1+\overline{\bar{i}}_{l t}\right) l_{t}$ captures the fixed cost of the firm. The residual capital needs of the firm is satisfied by the loans obtained from the curb market and hence the interest rate in the UMM enters as the relevant variable in the loan demand function.

The firm's problem can be written in the following recursive formulation: 


$$
\begin{aligned}
V\left(k_{t}\right)= & \max _{n, k \prime} p_{t} y_{t}-p_{t} w_{t} n_{t}-\left(1+i_{t}^{c}\right) p_{t}\left(k_{t+1}+\left(1-\delta_{k}\right) k_{t}-l_{t}\right)-p_{t}\left(1+\bar{i}_{l t}\right) l t \\
& +\rho V\left(k_{t+1}\right)
\end{aligned}
$$

The upshot of the above dynamic programming problem are the following first-order c conditions:

$$
\begin{aligned}
k_{t+1}:\left(l+i_{t}^{c}\right) p_{t} & =\rho V^{\prime}\left(k_{t+1}\right) \\
\left(n_{t}\right): y_{n t} & =w_{t}
\end{aligned}
$$

And the following envelope condition:

$V^{\prime}\left(k_{t}\right)=p_{t}\left[y k_{t+1}+\left(1+i_{t}^{c}\right)\left(1-\delta_{k}\right)\right]$

where $y_{n t}$ and $y k_{t+1}$ are the marginal product of capita with respect to labor and investment, respectively. Optimization leads to the following efficiency condition, as well as equation (22), for the production firm.

$$
\left(1+i_{t}^{c}\right)=\rho\left(\pi_{t+1}\right)\left[y k_{t+1}+\left(1+i_{t+1}^{c}\right)\left(l-\delta_{k}\right)\right]
$$

Equation (24) provides the condition for the optimal investment decision of the firm. The firm compares the cost of increasing investment in the current period with the future stream of benefit generated from the extra capital invested in the current period. Equation (22) simply states that the firm hires labor up to the point where the marginal product of labor equates the real wage.

With the production structure in equation (15) and given that $n_{t}=1$ and $k_{t}=\bar{k}_{t}$ will hold in equilibrium, $y_{n t}=A(1-\alpha) k_{t}$ and $y k_{t+1}=A \alpha$.

\subsection{Government and the External Sector}

In this subsection we describe the activities of an infinitely-lived government. The government purchases $g_{t}$ units of the consumption good and is assumed to costlessly transform these one-forone into what are called government goods. A government good is assumed to be useless to the agents. The government finances these purchases by income taxation, issuing government bonds and printing of fiat money. Formally, the government's budget constraint at date $t$ can be defined follows:

$$
p_{t} g_{t}=\tau_{t} p_{t} w_{t}+\left[M_{t}-M_{t-1}\right]+\left[B_{t}-B_{t-1}\right]
$$

where $M_{t}$ and $B_{t}$, respectively, are banks holding of fiat money and government bonds in nominal terms. We assume that money evolves according to the policy rule $M_{t}=\mu_{t} M_{t-1}$, 
where $\mu(>1)$ is the gross money growth rate.

Finally, the balance of payments identity of this economy, assuming that (PPP), i.e. $p=e p^{*}$ holds for all $t$, is given by: $b_{t}^{*}-\left(1+\tau_{t}^{*}\right) b_{t-1}^{*}=x_{t}-c_{t}^{*}$

where $r^{*}$ is the real rate of return on foreign bond holdings, i.e. $\left(1+r^{*}\right)=\left(\frac{1+i^{*}}{\pi^{*}}\right)$ for all $t$, and $x_{t}$ is the export. Note $\pi^{*}$ is the world rate of inflation. But, given that $p^{*}$ has been normalized to unity, the world rate of inflation is zero, therefore $r^{*}=i^{*}$ for all $t$. The identity, given by equation (26), implies the current account deficit, which is the interest payments obtained on foreign bonds $\left(r_{t}^{*} b_{t-1}^{*}\right)$ less the trade surplus $\left(x_{t}-c_{t}^{*}\right)$ has to be equal to the change in holdings of foreign bonds $\left(b_{t}^{*}-b_{t-1}^{*}\right)$. Without any loss of generality and maintaining consistency with perpetual growth, the exports of the economy, $x_{t}$, will be assumed to be a fixed fraction, $\phi$, of the domestic output. Alternatively, equation (26) becomes:

$b_{t}^{*}-\left(1+\tau_{t}^{*}\right) b_{t-1}^{*}=\varphi y_{t}-c_{t}^{*}$

\section{Equilibrium}

A valid, perfect-foresight, competitive equilibrium for this economy is a sequence of prices $\left\{p_{t}, e_{t}, \bar{i}_{d t}, \bar{i}_{l t}, i_{t}^{c}\right\}_{t=0}^{\infty}$, allocations $\left\{c_{t}, c_{t}^{*}, n_{t}, i_{k t}\right\}_{t=0}^{\infty}$, stocks of financial assets $\left\{m_{t}, d_{t}, l_{t}^{c}, b_{t}, b_{t}^{*}\right\}_{t=0}^{\infty}$, exogenous sequences of $\left\{p_{t}^{*}, i_{t}^{*}=\tau_{t}^{*}\right\}_{t=0}^{\infty}$, and policy variables $\left\{\tau_{t}, \bar{i}_{d t}, \bar{i}_{l t}, \gamma_{1 t}, \gamma_{2 t}, \mu_{t}, B_{t}\right\}_{t=0}^{\infty}$ such that:

- taking $\bar{i}_{d t}, \bar{z}_{l t},{ }_{t}^{i}, i_{t}^{i}, \tau_{t}, w_{t}, e_{t}$ and $p_{t}$, the consumer optimally chooses $c_{t+1}, c_{t+1}^{*}, d_{t} l_{t}^{c}$ and $b_{t}^{*}$, such that equation (1) is maximized subject to equations (2) and (3);

- the stock of financial assets, $m_{t}$ and $d_{t}$, solve the bank's date- $t$ profit maximization problem, equation (9), subject to equations (10), (11) and (12), given prices and policy variables.

- the real allocations solve the firm's date-t profit maximization problem, equation (16), subject to equations (17), (18) and (19), given prices and policy variables.

- the goods, money, loanable funds, labor and the bond market equilibrium condition is satisfied for all $t \geq 0$.

- the government budget, equation (25), is balanced on a period-by-period basis.

- the equilibrium condition in the external sector requires equation (27) to hold, along with the interest rate parity and PPP conditions being satisfied for all $t \geq 0$.

- $d_{t},{ }_{t}^{c}, b_{t}^{*}, m_{t}, b_{t}, \bar{i}_{d t}, \bar{l}_{t}, i_{t}^{c}, i_{t}^{*}, p_{t}=e_{t}$ and $p_{t}^{*}$ must be positive for all $t \geq 0$.

\section{Effects of Financial Liberalization on Growth and Inflation}

We will assume the government follows time invariant policy rules, which means that the institutionally determined nominal interest rate on deposits and loans, $\bar{l}_{d t}$ and $\bar{l}_{l}$, respectively, the 
tax rate, $\tau_{t}$, the cash reserve-ratio, $\gamma_{1 t}$, the bond reserve-ratio, $\gamma_{2 t}$, the money growth rate, $\mu_{t}$, are constant over time. Moreover, note that financial liberalization, in our context, would not only imply the increase in the interest rate on deposits $\left(\bar{l}_{d}\right)$, but also the lowering of the cash reserve $\left(\gamma_{1}\right)$ and the bond reserve $\left(\gamma_{2}\right)$ ratios.

Realizing that, in steady-state, all the real variables grow at the same rate, interest rates remain constant, and all markets clear, the following two expressions, obtained from equations (4), (6), (10), (11), (12), (17), (18), (19), (22) and (24), can be used to solve for the steady-state gross growth $(\theta)$ and inflation $(\pi)$ rate, ${ }^{11}$ given the production $(A$, aand $p)$ and policy $\left(\tau_{t}, \bar{l}_{d}, \gamma_{1}, \gamma_{2}\right.$ and $\mu$ ) parameters:

$$
\begin{aligned}
\theta= & (1-\delta)+A(1-\alpha)\left[\left(1-\gamma_{1}-\gamma_{2}\right)(1-\tau)+\left(\frac{\left(1-\gamma_{1}-\gamma_{2}\right)\left(c_{1}+c_{2}\right)}{c_{1} c_{2}}\right)\right. \\
& \left.-\left(\frac{1}{c_{1}}\right)\left(\overline{i_{d}}-i^{*}\right)\right] \\
\theta \pi= & \mu
\end{aligned}
$$

So we can solve for the gross growth rate from equation (28) directly, while, replacing the expression of the gross growth rate from equation (28) into equation (29), would yield us a qlosed-form solution for the gross rate of inflation. Note, given a constant money supply growth rate $(\mu)$, equation (29) indicates the widely observed inverse relationship between growth and inflation. ${ }^{12}$

As can be seen from equations (28) and (29) the effect of an interest rate deregulation, i.e. an increase in $\overline{i_{d}}$, will produce a positive (negative), negative (positive) or no effect on growth (inflation), based on whether $\left(1-\gamma_{1}-\gamma_{2}\right)\left(c_{1}+c_{2}\right) / c_{1} c_{2}$ is greater than, less than or equal to $1 / c_{1}$. Or alternatively, positive-growth and negative-inflation effects, following an interest rate liberalization, require that $\left(1-\gamma_{1}-\gamma_{2}\right)\left(c_{1}+c_{2}\right)>c_{2}$. This implies that the lower the transaction cost of operating in the curb market, i.e. the smaller the value of $c_{1}$, the higher the possibility that an increase in $\bar{i}_{d}$ will result in a fall in growth and a rise in inflation, given the size of the reserve requirements $\left(\gamma_{1}+\gamma_{2}\right)$ and the transaction cost parameter for operating in the foreign market $\left(c_{2}\right)$. Further, given $c_{1}$ and $\left(\gamma_{1}+\gamma_{2}\right)$, the lower the value of $c_{2}$, the higher the possibility of a positive (negative) growth (inflation) effect of an interest rate deregulation. On the other hand, as is evident from equation (28), lowering the reserve requirements on cash or bond, will unambiguously increase growth, and, hence, reduce inflation. Note, since the effect of reducing the reserve requirement on cash or on government bond would be identical ${ }^{13}$ we define, $\gamma_{1}+\gamma_{2}=\gamma$.

The theoretical analysis of the model is simple, but to get a better grasp of our results, we calibrate the model to match average values generally observed for developing economies, and study the effects of financial liberalization, on growth and inflation, quantitatively. The quantification also helps in indicating the strength of the effect of financial liberalization, 
emanating both through a higher interest rate on deposits and lower reserve requirements. The following parameter values were chosen initially and the sources are given in the parentheses: ${ }^{14}$ the tax rate, $\tau=0.25$ (Gupta, 2008), the reserve requirement, $\gamma=0.15$ (Haslag \& Young, 1998), the interest rate on the deposits $\overline{i_{d}}=0.10$ (Gupta, 2008) the elasticity of capital with respect to output, $\alpha=0.40$ (Zimmermann, 1997), the depreciation rate of capital, $\delta_{k}=0.05$ (Zimmermann, 1997), and the transaction cost parameters $c_{1}$ and $c_{2}=1.0$ (Gupta, 2008). The value of $A$, the production function scalar, is calibrated from the equilibrium conditions to match a growth rate of $2.5 \%(\theta=1.025)$ and an inflation rate of $5 \%(\pi=1.05)$, as suggested in Basu (2001), causing this to equal 0.2075 . Given the no arbitrage condition in the curb and foreign bonds market, $i_{c}=i^{*}\left(=r^{*}\right)$, we set the world rate of interest, $r^{*}$, to $15 \%$ as well. ${ }^{15}$ Finally, the gross money growth rate, $\mu$ is set at 1.071 , or a growth rate of $7.1 \%$, obtained from equation (28). Given these parameter values, Figures 1 and 2 plot the growth- and inflation-effects of varying the nominal interest rate on deposits, $\overline{i_{d}}$, between $5 \%$ and $14.5 \%$, thus ensuring that the curb market is not completely eradicated. As can be seen from the graphs labeled G1 and P1, in Figures 1 and 2 respectively, deregulation of the nominal interest rate on deposits is growth-enhancing and inflation-reducing. This is obvious since $\left(1-\gamma_{1}-\gamma_{2}\right)\left(c_{1}+c_{2}\right)(=1.70)>c_{2}(=1.00)$. Intuitively, this parameterization of the model ensures that the responsiveness of the curb market loans as a percentage of the capital stock with respect to $\overline{i_{d}}\left(\left(-1 / c_{1}\right) A(1-\alpha)\right)$ is less than the corresponding derivative of the bank loans as a percentage of the capital stock $\left((1-\gamma)\left(c_{1}+c_{2}\right) / c_{1} c_{2} A(l-\alpha)\right)$ in absolute terms. So the fall in the curb market loans as a percentage of capital due to a rise in the official interest rate is outweighed by the increase in the bank loans as a percentage of capital, and hence aggregate loans as a percentage of capital, which, in turn, leads to an increase in investment as a fraction of the capital stock or the gross growth rate. Given, the negative growth-inflation relationship, indicated by equation (29) the steady-state gross rate of inflation declines.

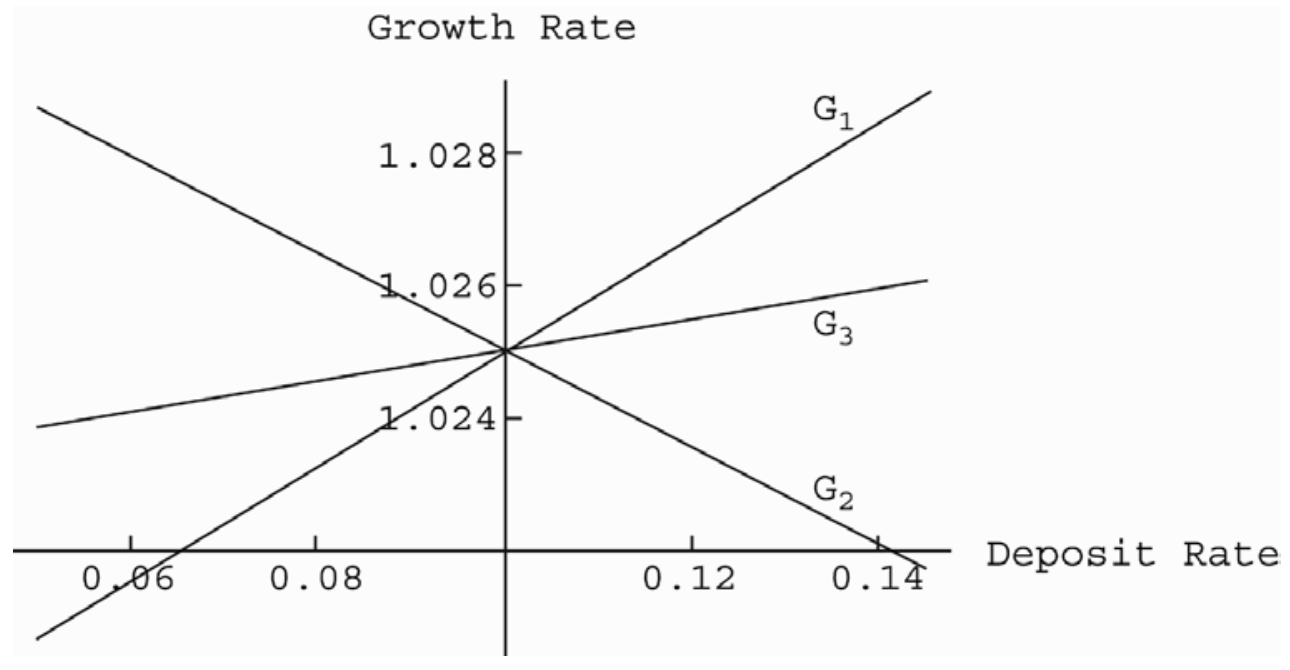

Figure 1. Interest rate deregulation and growth. 


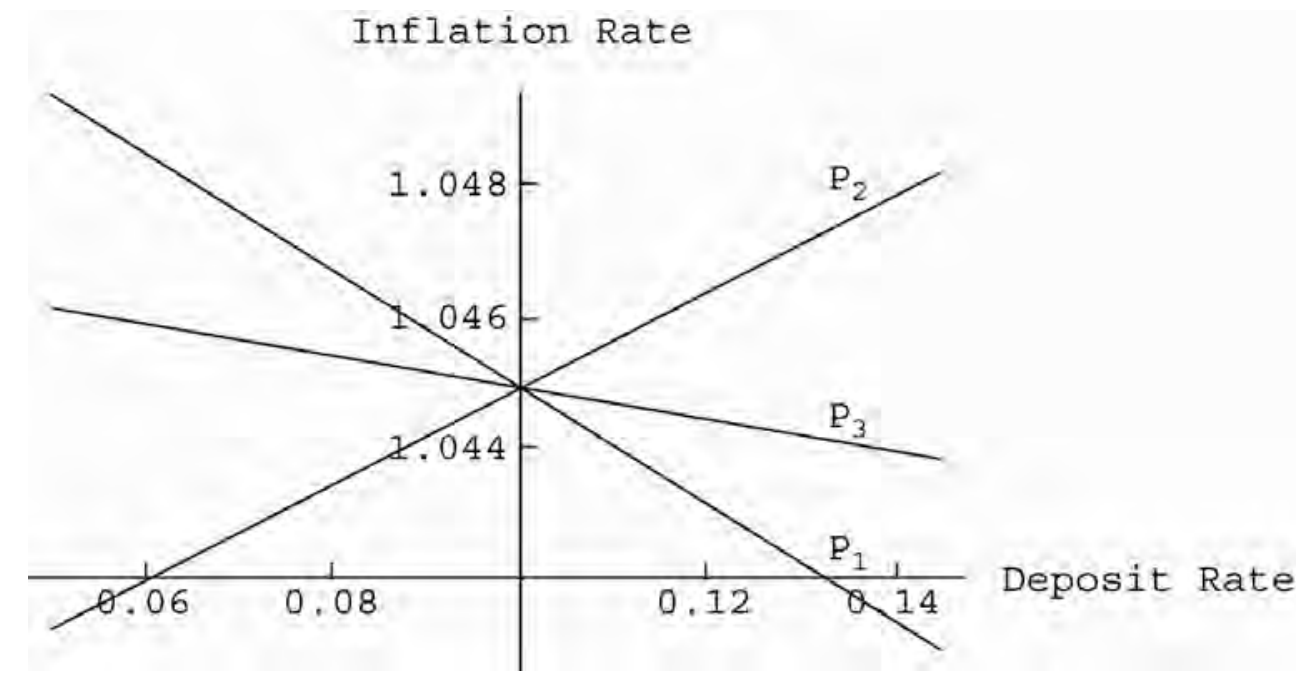

Figure 2. Interest rate deregulation and inflation.

Graphs G1 and P1, in Figures 3 and 4 respectively, analyze the effect of varying the reserve requirements, between 5 and 20\%, on growth and inflation, respectively. Lowering the reserve requirements by $1 \%$, increases the ratio of bank loans to capital by $d / k$ and, hence, aggregate loans as a percentage of capital. This, in turn, leads to an increase in investment as a fraction of the capital stock, and translates into higher growth and lower inflation in the steady-state.

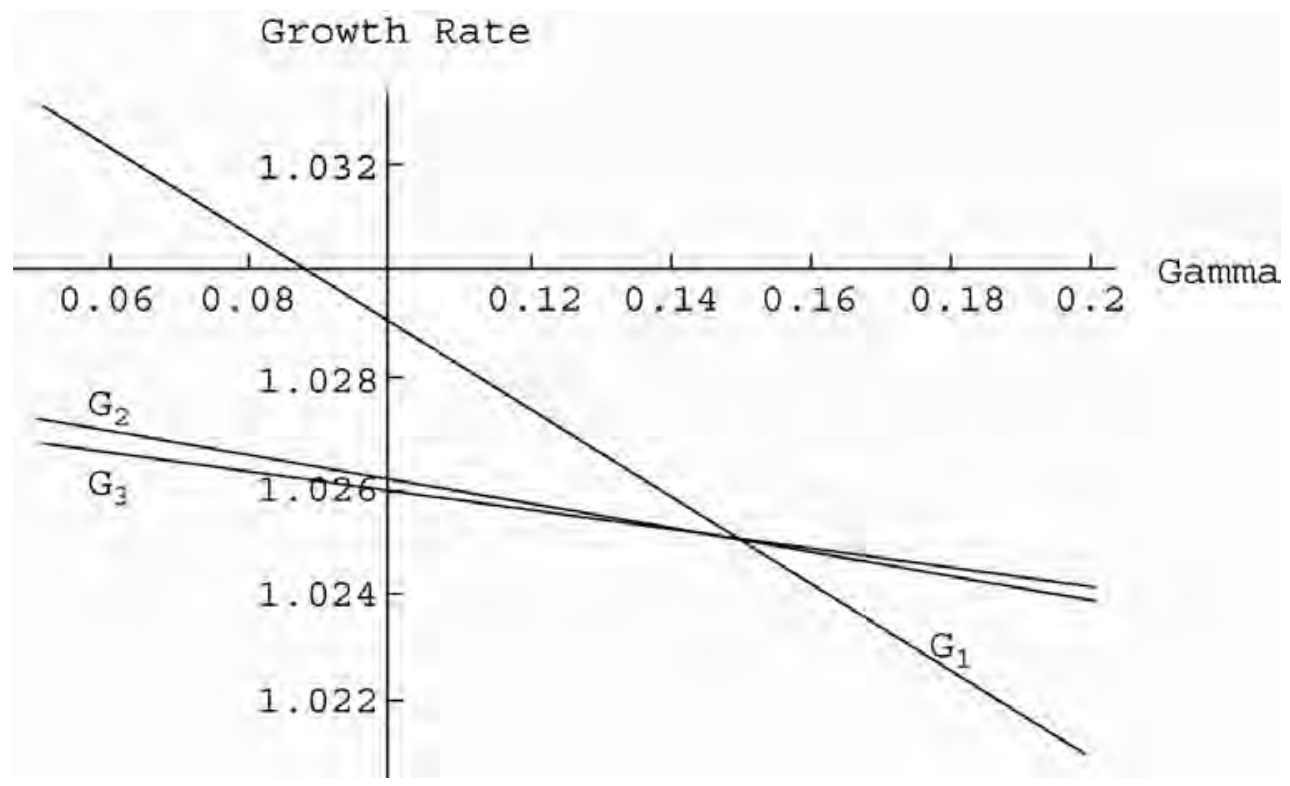

Figure 3. Reserve requirements and growth. 


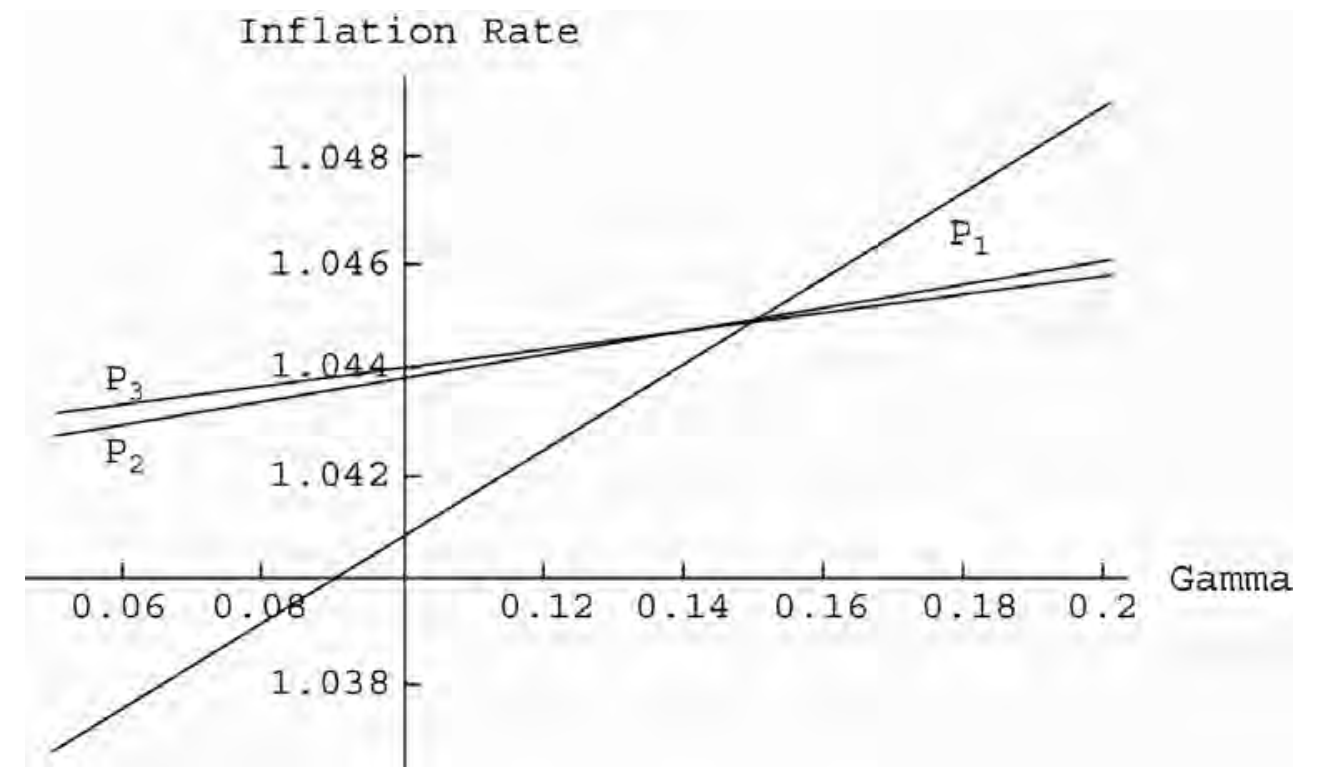

Figure 4. Reserve requirements and inflation.

Next, we reduce the transaction costs in the curb markets by lowering the value of $c_{1}$ to 0.1 from 1.0, and carry out the same set of experiments as above. The model is re-calibrated to obtain the new parameter values for $A$ to match the growth rate of $2.5 \%$. The revised value for $A$ is equal to 0.1866. In this case, an increase in the deposit rate reduces growth and enhances inflation, as seen from the graphs labeled G2 and P2 in Figures 1 and 2 respectively. This is understandably so, since now the fall in the ratio of curb market loans to the physical capital (-1.1194) outweighs the rise in the supply of bank loans to capital (1.0466), causing the ratio of investment to capital, and hence growth to fall and inflation to rise. However, the direction of the effect of lower reserve requirements on growth and inflation, as seen from G2 and P2 in Figures 3 and 4 respectively, remains the same as with the initial set of parameters, although the effect is now weaker. Note, the derivative of bank loans as a percentage of capital with respect to reserve requirements is given by: $-A(1-\alpha)\left[(1-\tau)+\left(c_{1}+c_{2} / c_{1} c_{2}\right)\left(\overline{i_{d}}-i^{*}\right)\right]$. With, $\overline{i_{d}}-i^{*}<0$, and a fall in $c_{1}$ increasing the size of $\left(\left(c_{1}+c_{2}\right) / c_{1} c_{2}\right)$ given $c_{2}$, the responsiveness of growth and inflation weakens to changes in the reserve requirements.

These experiments imply that the claim of the New-Structuralist school of inflation, following financial liberalization, depends crucially on the size of the transaction costs in the curb market, and, hence, the elasticities of the bank loans and curb market loans resulting from these cost parameters. In fact, Owen \& Solis-Fallas (1989) and Cho (1990) suggest that these transaction costs in the curb markets are likely to be (structurally) so high that, unlike the New-Structuralists' claims they would cause these markets to provide less intermediation than the official banking sector, subjected to reserve requirements. Under such a situation, then, interest rate deregulation is always growth enhancing and inflation reducing. However, when otherwise, then policies of financial liberalization should be targeted towards reduction of reserve requirements as such a policy, unambiguously, increases (decreases) growth (inflation), although lower transaction costs tend to weaken the strength of such effects.

Finally, we analyze the role played by lower values of transaction costs in the foreign bonds 
market. This, in turn, has important policy implications. For this experiment, we keep $c_{1}=0.1$ and choose a value of $c_{2}=0.50$. The resulting value for $A$, required to match the growth rate of $2.5 \%$, is 0.1992. $G_{3}$ and $P_{3}$ in Figures 1 and 2, respectively, show that interest rate deregulation is back to being growth-enhancing and inflation-reducing. This is because a lower transaction cost in the foreign bonds market increases the responsiveness of the deposits as a percentage of capital with respect to the bank interest rate (1.2191) beyond the size of the derivative of the curb market loans as a fraction of capital with respect to the same (-1.1952) in absolute terms. Hence, aggregate loans as a percentage of capital increase and so does growth. Given equation (29) this is accompanied by lower inflation. Note as long as $c_{2}<((1-\gamma) / \gamma) c_{1}$, i.e. in our case, for any value of $c_{2}$ below 0.5667, given $c_{1}=0.1$ and $\gamma=0.15$, interest rate deregulation will be growthenhancing and inflation-reducing.

Further, as depicted by $G_{3}$ and $P_{3}$ in Figures 3 and 4, respectively, the effect of varying the reserve requirements, between 5 and 20\%, on growth and inflation for these new sets of parameter values are weaker in comparison to the effects on the same for $c_{1}=c_{2}=1.0$ and $c_{1}=0.1$ and $c_{2}=1$, indicated by $G_{1}$ and $P_{1}$ and $G_{2}$ and $P_{2}$, respectively, in the same figures. Note that, with the derivative of bank loans as a percentage of capital with respect to reserve requirements given by $-A(l-\alpha)\left[(1-\tau)+\left(\left(c_{1}+c_{2}\right) / c_{1} c_{2}\right)\left(\overline{i_{d}}-i^{*}\right)\right]$ and with, $\overline{i_{d}}-i^{*}<0$, a fall in $c_{2}$ increases the size of $\left(\left(c_{1}+c_{2}\right) / c_{1} c_{2}\right)$ given $c_{1}$, and hence weakens the effect of lower reserve requirements in comparison to the scenarios where $c_{1}=c_{2}=1.0$ and $c_{1}=0.1$ and $c_{2}=1$.

The final experiment implies that, in economies where the curb markets are thriving, so that transaction costs are small, the government should strive to reduce the transaction costs in the foreign capital markets as a prerequisite for interest rate liberalization to be growth enhancing and inflation reducing. Lower transaction costs in the foreign bonds market enhance the elasticities of the supply of deposits and bank loans with respect to the deposit rate, and ensure desirable effects on growth and inflation following interest rate deregulation. In light of all this, one should not forget that, perhaps, the most important reason behind this result (even before the government attempts to reduce impediments to transaction in the foreign capital market, arising due to governmental regulation or lack of transparency regarding the laws and rules for operation of the traders in this market) is that the economy should have a flexible exchange rate regime and perfect capital mobility in place. Alternatively, if the transaction costs in the curb markets are structurally high, as pointed out above, the government can strengthen the effects of interest rate deregulation on growth and inflation in a desirable direction, by enhancing the transaction costs in the foreign capital market.

\section{Conclusions and Areas of Further Research}

This paper develops a monetary endogenous growth model of a financially repressed small open economy in an overlapping generations framework, characterized by Unofficial Money Markets (UMM), or curb markets as they are popularly called, the capital mobility, costs involved in carrying out transactions in domestic and foreign capital markets, and a flexible exchange rate system, to analyze the impact of financial liberalization on growth and inflation. In the process, it attempts to fill the gap in the literature regarding microfounded monetary endogenous growth models for small open economies, subjected to financial restrictions, which can also be quantitatively analyzed. Moreover, it points out the role of capital mobility, flexible exchange 
rates and transaction costs in the domestic and foreign capital markets, in shaping the outcomes of a policy of financial deregulation.

Given that financial liberalization, in our context, would not only imply an increase in the interest rate on deposits, but also the lowering of multiple reserve ratios, the following conclusions can be drawn: (i) if transaction costs in the curb markets are structurally so high that it would cause these markets to provide less intermediation than the official banking sector, interest rate deregulation is always growth enhancing and inflation reducing, in such a situation. However, when otherwise, then policies of financial liberalization should be targeted towards reduction of reserve requirements, for such a policy unambiguously increases (decreases) growth (inflation); (ii) if the transaction costs in the curb markets are structurally high, the government can strengthen the effects of financial liberalization on growth and inflation in the desired direction through the imposition of stricter regulations in the foreign bonds market, and hence enhance the cost of transactions in this market; (iii) for economies where the curb markets are thriving, so that transaction costs are small, the government should strive to reduce the transaction costs in the foreign capital markets as a pre-requisite for financial liberalization to be growth enhancing and inflation reducing. Lower transaction costs in the foreign bonds market enhances the elasticities of the supply of bank loans and ensure desirable effects on growth and inflation following financial deregulation. This paper, thus, suggests that depending upon the nature of the cost of transaction in the curb markets, the government will have diametrically opposite roles to pursue in order to ensure higher growth and lower inflation, following interest rate deregulation.

In our model, public expenditure is purposeless, which to be honest is an extreme assumption, especially for developing economies, where public capital plays an important role in the growthgenerating process. Hence, to assume that the entire revenue generated from repressive policies is used to finance the budget deficit would be a mistake. Such an assertion is also vindicated by recent studies of Aschauer (1989), Barro (1990), Roubini \& Sala-i-Martin (1992), Cuikerman et al. (1992), Adam et al. (1996), Agbonytor (1998) and Basu (2001). All these studies point out that, in developing economies, seigniorage is an important way of financing public expenditure and, when used purposefully, would be growth-augmenting. Basu (2001) computes the crosscountry correlation between the annual average seigniorage rate and the public investment rate to be at 0.12 in 68 countries over the period of 1970-97. Once the top-third high-inflation countries in the sample were dropped the figure measured 0.47 and was significant at the $5 \%$ level. Hence, ignoring the productive role of public expenditures in developing economies, while analyzing financial deregulation, can lead to drawing incorrect policy conclusions. In this regard, an immediate extension, of the above analysis would be to incorporate public good in the production structure, at least a fraction of it, and re-analyze the robustness of the results of the current paper. 


\section{References}

Adam, C. , Ndulu, B. and Sowa, N. K. (1996) Liberalization and seigniorage revenue in Kenya, Ghana and Tanzania. Journal of Development Studies_32:4 , pp. 531-553.

Agbonytor, A. D. K. (1998) Development expenditures and the local financing constraint. World Bank Report on Eastern Africa

Aschauer, D. A. (1989) Is public expenditure productive?. Journal of Monetary Economics 23:2, pp. 177-200.

Bacchetta, P. and Caminal, R. (1992) Optimal seigniorage and financial liberalization. Journal of International Money and Finance 11:5 , pp. 518-538.

Barro, R. J. (1990) Government spending in a simple model of endogenous growth. Journal of Political Economy 98:5 Part 2, pp. S103-S125.

Barro, R. J. (1995) Inflation and economic growth. Bank of England Quarterly Bulletin 35 , pp. 166-176.

Basu, P. (2001) Reserve ratio, seigniorage and growth. Journal of Macroeconomics 23:3 , pp. 397-416.

Bencivenga, V. R. and Smith, B. D. (1991) Financial intermediation and endogenous growth. Review of Economic Studies 58:2 , pp. 195-209.

Bhattacharya, J. and Haslag, J. H. (2001) On the use of inflation tax when nondistortionary taxes are available. Review of Economic Dynamics 4:4 , pp. 823-841.

Buffie, E. E. (1984) Financial repression, the new structuralists, and stabilization policy in semiindustrialized economies. Journal of Development Economics 14:3 , pp. 305-322.

Chari, V. V. , Manuelli, R. E. and Jones, L. E. (1995) The growth effects of monetary policy. Quarterly Review, Federal Reserve Bank of Minneapolis 19:4 , pp. 18-32.

Chen, B. -L. , Chiang, Y. -Y. and Wang, P. (2000) Credit market imperfections, financial activity and economic growth. — Vanderbilt University Working Paper 00-W20

Cho, Y. J. (1990) McKinnon-Shaw versus the neostructuralists on financial liberalization: a conceptual note. World Development 18:3 , pp. 477-480.

Christensen, G. (1993) The limits of informal financial intermediation. World Development 21:5 , pp. 721-731.

Cuikerman, A. , Sebastian, E. and Tabellin, G. (1992) Seigniorage and political instability. 
American Economic Review 82:3 , pp. 537-555.

Dasgupta, B. (2004) Capital accumulation in the presence of informal credit contracts: does the incentive mechanism work better than credit rationing under asymmetric information?. Working Paper Series, 2004-32 . University of Connecticut

Dasgupta, B. (2005a) Endogenous growth in the presence of informal credit markets: a comparative analysis between credit rationing and self-revelation. Working Paper Series, 200518 . University of Connecticut

Dasgupta, B. (2005b) Liquidity constraint and child labor in India: is market really incapable of eradicating it from wage-labor households. Working Paper Series, 2005-37 . University of Connecticut

Diamond, P. A. (1965) National debt in a neoclassical growth model. American Economic Review 55:5 , pp. 1126-1150.

Diamond, P. and Yellin, J. (1990) Inventories and money holdings in a search economy. Econometrica 58:4, pp. 929-950.

Espinosa, M. and Yip, C. K. (1996) An endogenous growth model of money, banking, and financial repression. Working Paper 96-04 . Federal Reserve Bank of Atlanta

Feenstra, R. C. (1986) Functional equivalence between liquidity costs and the utility of money. Journal of Monetary Economics 17:2 , pp. 271-291.

Fischer, S. Blanchard, O. and Fischer, S. (eds) (1991) Growth, macroeconomics and development. NBER Macroeconomics Annual 19916 , pp. 329-364. MIT Press/NBER 1991, Cambridge Massachusetts

Fung, M. K. Y. , Ho, W. -M. and Zhu, L. (1999) Effects of government policy changes on the private sector development of a transitional economy: a long-run analysis. Journal of Economic Development 24:2 , pp. 19-41.

Gupta, K. L. and Lensink, R. (1996) Financial Liberalization and Investment Routledge, New York

Gupta, R. and Karapatakis, A. G. (2008) Financial liberalization: a myth or a miracle cure? ICFAI Journal of Monetary Economics 6:1 , pp. 6-33.

Gupta, R. (2007) Financial liberalization and inflationary dynamics: an open economy analysis. International Economic Journal 21:3 , pp. 335-360.

Gupta, R. (2008) A generic model of financial repression. International Economics and Finance Journal 3:1 , pp. 1-22. 
Gupta, R. (2009) Financial liberalization and inflationary dynamics. International Journal of Economic Research 6:1, pp. 127-145.

Hall, R. E. (1988) Intertemporal substitution in consumption. Journal of Political Economy 96:2 , pp. 339-357.

Haslag, J. E. and Youngs, E. R. (1998) Money creation, reserve requirements, and seigniorage. Review of Economic Dynamics 1:3 , pp. 677-698.

Kan, K. (2000) Informal capital sources and household investment: evidence from Taiwan. Journal of Development Economics 62:1 , pp. 209-231

. Kang, S. J. and Sawada, Y. (2000) Financial repression and external openness in an endogenous growth model. Journal of International Trade and Economic Development_9:4 , pp. 427-443.

Kapur, B. K. (1976) Alternative stabilization policies for less developed economies. Journal of Political Economy 84:4 Part 1, pp. 777-795.

Kohsaka, A. (1984) The high interest rate policy under financial repression. The Developing Economies 22:4 , pp. 419-452.

Lim, J. (1987) The new structuralist critique of the monetarist theory of inflation: the case of the Philippines. Journal of Development Economics 25:1 , pp. 45-61. 37. Mathieson, D. J. (1980) Financial reform and stabilization policy in a developing economy. Journal of Development Economics 7:3 , pp. 359-395.

McKinnon, R. I. (1973) Money and Capital in Economic Development Brookings Institution Press , Washington, DC

Montiel, P. J. , Agénor, P. -R. and Ul Haque, N. (1993) Informal Financial Markets in Developing Countries: A Macroeconomic Analysis Basil Blackwell , Oxford

Owen, P. D. and Solis-Fallas, O. (1989) Unorganized money markets and unproductive assets in the new structuralist critique of financial liberalization. Journal of Development Economics 31:2 , pp. 341-355.

Romer, P. (1986) Increasing returns and long-run growth. Journal of Political Economy 94:5, pp. 1002-1037.

Roubini, N. and Sala-i-Martin, X. (1992) Financial repression and economic growth. Journal of Development Economics 39:1, pp. 5-30.

Roubini, N. and Sala-i-Martin, X. (1995) A growth model of inflation, tax evasion, and financial repressions. Journal of Monetary Economics 35:2 , pp. 275-301.]

Shaw, E. S. (1973) Financial Deepening in Economic Development Oxford University Press, 
New York

Taylor, L. (1983) Structuralist Macroeconomics: Applicable Models for the Third World Basic Books, New York

Van Wijnbergen, S. (1982) Stagnationary effects of monetary stabilization policies: a quantitative analysis of South Korea. Journal of Development Economics 10:2 , pp. 133-169.

Van Wijnbergen, S. (1983) Interest rate management in LDCs. Journal of Monetary Economics $12: 3$, pp. 433-452.

Van Wijnbergen, S. (1985) Macro-economic effects of changes in bank interest rates: simulation results for South Korea. Journal of Development Economics 18:2-3 , pp. 541-554.

Walsh, C. E. (2000) Monetary Theory and Policy 2, MIT Press , Cambridge, MA

Wang, P. and Chong, K. Y. (1992) Alternative approaches to money and growth. Journal of Money, Credit and Banking 24:2 , pp. 553-562.

Zimmermann, C. (1997) Technology innovations and the volatility of output: an international perspective. Working Paper 34 . CREFE

\section{Notes}

${ }^{1}$ See Gupta \& Karapatakis (2008) for a detailed review on financial liberalization spanning more than three decades.

${ }^{2}$ For analyses of financial liberalization in endogenous growth models for closed economies, see Bencivenga \& Smith (1991), Roubini \& Sala-i-Martin (1995), Espinosa \& Yip (1996), Chari et al. (1995), Fung et al. (1999) and Gupta (2009). All these studies conclude that financial repression, in general, is inflationary and reduces growth.

${ }^{3}$ This assumption has no bearing on the results of our model. It makes computations easier and also seems to be a good approximation of the reality. For details see Hall (1988).

${ }^{4}$ Adding another asset like domestic money, via a cash-in-advance constraint, allowing for (domestic and imported) cash- and credit-goods does not change our conclusions, but merely complicates the computations. Hence, cash requirements to meet consumption has been ignored from the consumer-portfolio.

${ }^{5}$ The assumed additively separable log-utility function is a special case of the general function $U=\left[\sigma c_{t+1}^{1-\lambda}+(1-\sigma) c_{t+1}^{* 1-\lambda}\right]^{1 /(1-\lambda)}$, with $\lambda=1$. Note $1 / \lambda$ is the elasticity of substitution between the domestic and the imported good. The choice of the utility function has no bearing on the results of the model we are interested in.

${ }^{6}$ Note in equilibrium the ratio of the transaction costs with respect to real wage is constant, as all 
real variables grow at the same rate.

${ }^{7}$ Similar specifications of transaction and information costs are assumed in Bacchetta \& Caminal (1992) and Haslag \& Young (1998) in reference to foreign and non-bank financial intermediary deposits respectively.

${ }^{8}$ Note as the economy grows, so does the capital stock and the real wage. See subsection 2.3 for further details.

${ }^{9}$ See Gupta \& Karapatakis (2008) for details.

${ }^{10}$ This assumption allows us to avoid incorporating government bonds in the household portfolio and helps us to negate a plausible multiplicity of optimal allocations of deposits and government bonds that would have cropped up, given that households would not hold government bonds unless they promised a return at least as large as the bank deposits. However, assuming that the government bonds yield a positive nominal rate of return but lower than the interest rate on deposits, would have no bearing on our results and would merely change the profit function of the banks.

${ }^{11}$ Given that purchasing power parity holds, the movement in the steady-state inflation rate exactly mirrors the movements of the steady-state level of exchange rate depreciation of domestic currency.

${ }^{12}$ The two widely known papers that document a negative association between inflation and the growth rate of output are Fischer (1991) and Barro (1995).

${ }^{13}$ The multiple reserve requirements have been mainly introduced, in this paper, to depict a more realistic financially repressed system. So they can be ignored without affecting the results of our analysis involving reserve requirements.

${ }^{14}$ The parameter values, obtained from different studies have been rounded off to the nearest multiples of 5 .

${ }^{15}$ Note the world interest rate is clearly a bit higher than the average values observed for developed economies, but is clearly a fallout of one the equilibrium conditions of the model. This, however, has no qualitative implications, since the condition $\left(\left(1-\gamma_{1}-\gamma_{2}\right)\left(c_{1}+c_{2}\right)>c_{2}\right)$ driving the results of our model, is independent of the choice of this value. 